\title{
Kompetensi konseling multikultural: Menjadi pribadi melek literasi global
}

\author{
Azmi Mustaqim \\ IAIN Ponorogo \\ Mustaqim.azmi10@gmail.com
}

\begin{abstract}
Abstrak
Pengembangan literasi global tidak hanya cukup dengan kemampuan seseorang dalam membaca, menulis dan berhitung. Akan tetapi lebih dari itu, literasi global merupakan proses seumur hidup manusia yang berakar pada komitmen untuk menjalani kehidupan dengan cara menjadikan keragaman budaya sebagai prinsip utama. Tulisan ini hendak memotret sisi lain dari kompetensi konselor lintas budaya. Penulis meyakini bahwa keragaman budaya tidak hanya bisa dipelajari melalui buku-buku, penulisan-penulisan ilmiah ataupun seminar, akan tetapi pengalaman hidup konselor dan komitmennya terhadap keragaman kehidupan menjadi salah satu titik sentral. Tulisan ini merupakan studi literatur yang menggunakan analisis deskriptif sebagai metode analisis data. Hasil dari kajian ini adalah konselor perlu merefleksikan ulang pandangannya bahwa konselor profesional adalah cara hidup. Kehidupan seseorang harus dijalani dengan cara yang mencerminkan komitmen untuk terus memperluas zona kenyamanan budaya seseorang untuk memasukkan pengetahuan dan interaksi aktif dengan orang-orang dari berbagai latar belakang budaya. Ini berarti seseorang secara konstan menyadari bagaimana peristiwa, baik di masa lalu maupun saat ini berdampak pada kesejahteraan seseorang. Oleh sebab itu, literasi global tidak dapat dipelajari di ruang kelas, melainkan hal itu adalah upaya seseorang untuk menjadi pembelajar seumur hidup dari keragaman budaya dan warga dunia.
\end{abstract}

\section{Kata kunci: Konseling Multikultural, Konselor, Literasi Global, Budaya}

\begin{abstract}
The development of global literacy is not only enough for one's ability to read, write and count. However, more than that, global literacy is a human lifelong process which is rooted in a commitment to lead the life that makes cultural diversity as a core principal. This study would like to capture the other side of counselor cross-cultural competency. The writer believes that cultural diversity can't be learned from books, scientific papers, or seminar, but counselor's life experience and his/her commitment to diversity of life is a central point. This is a
\end{abstract}


study literature by using descriptive analysis as an analysis method. The results of this study are counselor needs to reflect his/her perspective that being professional counselor is a way of life. Human life should be lived in a manner that reflects a commitment to continually expanding one's cultural comfort zone to include knowing and active interaction with people form one's cultural backgrounds. It also mean that one constantly realize of how events, both past and current, impact on people's well-being. Therefore, global literacy cannot be learned in a classroom, rather, it is the one's effort to become a lifelong learner from cultural and citizen of the world diversity.

\section{Keyword: Multicultural Counseling, Counselor, Global Literacy, Culture.}

\section{PENDAHULUAN}

Literasi merupakan agenda utama dalam kerangka membangun peradaban umat manusia yang unggul. Kemajuan sebuah bangsa tidak cukup hanya mengandalkan sumberdaya alam yang dimiliki serta ledakan demografi yang melimpah. Akan tetapi bangsa yang besar ditandai dengan masyarakat yang literat, berperadaban tinggi dan aktif memajukan masyarakat dunia. Artinya budaya literasi yang tinggi dari suatu bangsa nampak pada kemampuan bangsa tersebut berkolaborasi, berfikir kritis, kreatif, komunikatif serta mampu memberikan pengaruh dalam persaingan global. Melalui literasi diharapkan tumbuh kesadaran kritis dari masyarakat untuk mengetahui sesuatu yang baru atau mengasimilasikannya dengan pengetahuan yang telah diketahui sebelumnya. Bangsa yang demikian adalah bangsa yang masyarakatnya berperadaban tinggi sehingga mampu bersaing dengan bangsa-bangsa lain.

Dalam konteks masyarakat Indonesia, kemampuan literasi sangat dibutuhkan mengingat keragaman suku, agama, budaya, bahasa, adat dan ras. Di satu sisi, heterogenitas masyarakat menjadi kekayaan tersendiri bagi bangsa. Namun di sisi lain, ini juga menjadi tantangan tersendiri bagi kehidupan berbangsa dan bernegara. Kemampuan literasi menjadi salah satu ukuran kemajuan suatu bangsa. Survey yang dilakukan Central Connecticut State University pada Tahun 2016 tentang literasi menempatkan Indonesia dalam posisi memprihatinkan, yaitu menempati urutan ke-60

dari 61 negara (Kementerian Pendidikan dan Kebudayaan, 2017). Hal itu mengindikasikan bahwa budaya literasi bangsa ini masih lemah perlu lebih digalakkan 
lagi. Ini penting dilakukan mengingat Pertama, keragaman etnis yang menjadi salah satu tantangan tersendiri bagi bangsa. Kedua, sebagai upaya pembangunan peradaban masyarakat yang unggul.

Selain dibutuhkan dalam konteks masyarakat heterogen, kemampuan literasi juga dibutuhkan mengingat perubahan sosial terjadi begitu cepat akibat pengaruh globalisasi dan perkembangan teknologi informasi. Globalisasi mendorong masyarakat menjadi terbuka dalam segala aspek kehidupan. Di era keragaman dan globalisasi, pengembangan kompetensi budaya menjadi penting sebagai seperangkat keterampilan adaptif yang berhasil dalam lingkungan seseorang (Wibowo, 2018). Persebaran budaya ke seluruh penjuru dunia didukung oleh teknologi informasi. Sehingga memaksa masyarakat untuk menggali informasi, pengetahuan dan, mempelajari budaya baru di luar budayanya sendiri. Artinya adalah, globalisasi mendorong budaya lokal menyebar ke penjuru dunia tanpa mampu dihambat, begitu juga budaya internasional akan mudah bersandingan dengan budaya lokal yang tidak mungkin dicegah.

Belum selesai pada tantangan keragaman budaya serta globalisasi, muncul teknologi informasi sebagai konsekuensi dari globalisasi. Era informasi ini disebut oleh Ghafur sebagai 'Renaissance' kedua (Ghafur, 2014). Gelombang globalisasi yang dipacu oleh teknologi ini telah melahirkan budaya baru selain budaya dunia, yakni budaya maya atau cyber culture (Wibowo, 2018). Keberadaanya semakin membuka hubungan lintas budaya, lintas agama, lintas etnis dan terbukanya berbagai macam referensi pengetahuan. Globalisasi benar-benar disokong oleh keberadaan teknologi informasi, pun demikian dengan persebaran budaya. Oleh sebab itu, manusia perlu dibekali dengan kemampuan membaca (literasi) yang cukup untuk beradaptasi dengan zaman.

Keragaman, globalisasi dan teknologi informasi merupakan suatu keniscayaan kehidupan hari ini. Terkait hal tersebut, manusia perlu melakukan adaptasi dan penyesuaian. Selain itu manusia perlu meningkatkan pengetahuannya dalam bingkai menguatkan literasi. Literasi bukan hanya dipahami sebagai kemampuan membaca (huruf), menulis dan menghitung (angka). Ia adalah suatu kondisi kemampuan seseorang dalam membaca situasi. Kemampuan membaca situasi bergantung pada tingkat 
pemahaman, seberapa banyak pengetahuan yang dimiliki seseorang tersebut. Kemampuan literasi ini dibutuhkan oleh semua profesi, yang termasuk juga di dalamnya adalah profesi bantuan (helping profession), seperti halnya konseling.

Pentingnya kesadaran berliterasi sangat mendukung keberhasilan seseorang dalam menangani berbagai macam persoalan. Jika dikaitkan dengan konteks konseling, penanganan berbagi macam persoalan yang dilakukan oleh seseorang merupakan pengertian dari konseling itu sendiri. Artinya Helping profession seperti halnya konseling membutuhkan kemampuan literasi yang cukup. Kecakapan seorang konselor dalam membantu menyelesaikan persoalan-persoalan keragaman budaya, problemproblem sosial akibat globalisasi dan teknologi informasi membutuhkan kemampaun literasi. Konselor dalam setiap kegiatan konseling perlu memahami latar belakang budaya konseli, artinya peningkatan literasi terhadap kebudayaan merupakan sebuah keharusan.

Untuk memahami budaya, perlu banyak membaca, menggali berbagai macam referensi dan pengalaman-pengalaman beriteraksi dengan beragam masyarakat. Lebih dari itu, mengingat banyaknya persoalan, mulai dari keragaman, globalisasi serta kemajuan teknologi informasi, kemampuan membaca bukan saja berarti penting, namun sangat dibutuhkan. Karena hal itu, kegiatan konseling perlu responsif secara budaya, atau disebut sebagai konseling kompeten secara budaya. Bukan tidak mungkin dalam setiap proses konseling, konselor akan menghadapi fakta-fakta latar belakang keragaman konselor, keragaman sejarah latar belakang, perbedaan pandangan, sistem lingkungan dan segala sesuatu yang berkaitan dengan konseli. Dan tidak mungkin untuk menjadi konselor yang kompeten secara budaya hanya menguasai praksis keilmuan konseling saja tanpa memahami keilmuan lain. Dengan berkembangnya era, berkembangnya pengetahuan, mustahil sebuah keilmuan mampu menopang dirinya sendiri dalam menyelesaikan problem. Tentu memerlukan sumbangsih dari keilmuan lain. Oleh sebab itu, memiliki pengetahuan lain misalnya sejarah, sosiologi, antropologi, agama, politik, ekonomi dan pengetahuan lainnya dibutuhkan oleh konselor multibudaya. 
Oleh karena itu, idealnya, agar benar-benar kompeten secara budaya sebagai konselor profesional, seseorang harus mempelajari sejarah, antropologi, sosiologi, ekonomi, agama, politik, dan sejumlah disiplin ilmu sosial lainnya dalam upaya mengembangkan basis pengetahuan untuk benar-benar memahami dinamika budaya berbagai kelompok masyarakat. Atau seseorang dapat berkomitmen untuk menjalani kehidupan yang benar-benar terbuka untuk mengalami keragaman budaya dalam semua aspeknya. Tulisan ini mencoba mendiskusikan basis literasi global sebagai bentuk yang lebih luas daripada literasi budaya yang harus dipahami konselor dalam kompetensi konseling multibudaya. Selain itu, kajian ini juga hendak mengeksplorasi literasi global sebagai aspek dasar tidak hanya kompetensi konseling multikultural tetapi juga cara hidup yang konsisten dengan beragam realitas masyarakat dunia.

\section{PEMBAHASAN}

\section{Mendefinisikan Konseling Multikultural}

Konseling multikultural dipandang sebagai kekuatan baru dalam perkembangan paradigma konseling. Pendahulunya ada paradigma Psikoanalisis, kemudian behavioris, lalu humanis, baru setelah itu muncul multikultural. Konseling multikultural didefinisikan sebagai gabungan kerja antara konselor dan konseli yang mempertimbangkan dinamika kepribadian antara keduanya sebagai pertimbangan bersamaan dengan dinamika budaya kedua individu. Konseling multikultural mempertimbangkan latar belakang budaya dan pengalaman individu konseli yang beragam dan bagaimana kebutuhan psikososial mereka dapat diidentifikasi dan dipenuhi melalui konseling (Lee \& Park, 2013; Sue \& Sue, 2012). Konseling multikultural tidak hanya mempertimbangkan karakteristik kepribadian konseli, melainkan lebih dari itu, yakni memahami secara holistik pengaruh-pengaruh yang membentuk karakteristik dan kepribadian konseli.

Konseling multikultural merupakan kegiatan konseling yang dilakukan dalam keragaman budaya (Supriatna, M: 2009), bukan hanya satu atau dua budaya konselor dan konseli melainkan bisa lebih banyak budaya. Sue dalam bukunya menyebut konseling multikultural ini dilakukan pada masyarakat minoritas dan marginal (Sue \& 
Sue, 2012). Konseling ini akan terjadi bila suatu proses konseling melibatkan perbedaan-perbedaan budaya antara konselor dan konseli di mana dalam proses itu rawan terjadinya bias-bias budaya yang dikhawatirkan akan mengganggu jalannya proses konseling.

Menurut Pedersen basis dari teori multikulturalis adalah gagasan bahwa konselor dengan konseli melibatkan variabel budaya yang berkaitan dengan misalnya usia, jenis kelamin, orientasi seksual, latarbelakang etnis, agama serta status sosial ekonomi(Pedersen, 1991). Tiap-tiap konseli datang dalam sebuah sesi konseling dengan membawa pandangan yang unik tentang dunianya, dibentuk oleh beragam pengalaman pribadi, dipengaruhi oleh sistem yang berlaku di masyarakat. Interaksi antar individu merupakan suatu bentuk pertemuan budaya, oleh sebab itu perhatian akan budaya keduanya tidak bisa dielakkan. Konsekuensinya adalah pemahaman dan kesadaran multikultural berkaitan erat dengan kemampuan penyesuaian diri, adaptasi, menerima perbedaan, membangun hubungan yang baik, mencegah dan mengatasi konflik yang berakar dari budaya.

Paradigma multikulturalisme menuntut sikap seseorang menjadi berfikir pluralis, artinya individu mau mengakui, menerima dan berkomitmen terlibat aktif merawat keragaman karena ia memahami bahwa keragaman adalah realitas. Berfikir pluralis artinya seseorang mengakui adanya kemajemukan dan ajakan untuk bersikap toleran terhadap kemajemukan itu sendiri. Namun pluralis menitikberatkan adanya komitmen keterlibatan aktif dan besikap positif dalam kemajemukan (Wijaya, 2019). Ia terlibat aktif dan secara positif karena meyakini perbedaan adalah sifat yang alamiah.

Di dalam permendikbud nomor 111 tahun 2014 tentang Bimbingan dan Konseling pada Pendidikan Dasar dan Pendidikan Menengah pasal 5 poin (a) dan (h), pelaksanaan bimbingan dan konseling harus sesuai dengan prinsip tidak diskriminatif dan dalam bingkai budaya Indonesia (Kemendikbud, 2014). Prinsip tidak diskriminatif ini mensyaratkan konselor untuk peka terhadap keragaman konseli. Konselor diminta untuk memiliki kesadaran untuk tidak menilai seseorang dari latar budaya yang berbeda. Dalam poin (h) secara jelas prinsip bimbingan dan konseling harus terbingkai dalam budaya bangsa. Interaksi antara konselor dan konseli sudah selayaknya berpedoman 
pada nilai-nilai adat dan budaya dimana konselor dan konseli tinggal. Konselor harus mempertimbangkan setting budaya dimana konselor bekerja menangani masalah.

Kompetensi multikultural sangat penting untuk dikuasai oleh seseorang karena berkaitan dengan pengalamannya. Apa yang seseorang lihat, bagaimana ia memahami apa yang ia lihat, bagaimana ia bersikap tentang pemahamannya, dan bagaimana seseorang tersebut mengekspresikan diri. Sikap-sikap inilah yang kemudian memberi pengaruh pada kehidupan seseorang. ketidakmampuan seseorang dalam memahami identitas budaya, serta kegagalan dalam merespon pengaruh-pengaruh sosial dapat menjadi sumber-sumber konflik dan hambatan dalam interaksi sosial. Seseorang harus memiliki kesadaran bahwa tiap-tiap manusia memiliki budaya sendiri yang tidak sama dengan lainnya. Dan, seseorang juga tidak bisa memaksakan budayanya untuk diikuti orang lain, melainkan manusia hanya mampu menerima dan memahami keragaman budaya itu. Maka dalam bahasa agama li kulli ra'sin ra'yun. Bahwa setiap manusia memiliki pendapat masing-masing, di mana pendapat itu muncul berpijak pada latar belakang (budaya) masing-masing orang.

\section{Konseling: Proses Perjumpaan Multi Budaya}

Identifikasi konselor terhadap konseli dalam proses konseling tidak mungkin terlepas dari sudut pandang budaya. Pertanyaan-pertanyaan mendasar tentang identitas konseli menjadi sangat penting untuk dicatat dalam sesi pertemuan pertama praktik konseling. Tanpa itu, gambaran proses konseling akan kabur dan jauh dari tujuan. Pertanyaan-pertanyaan yang berkaitan dengan asal usul, tempat tinggal sudah menjadi jelas menyasar pada dimensi kebudayaan. Dalam proses ini, konselor memasuki pada wilayah pengetahuan budaya sendiri serta mencoba menyelami budaya konseli.

Umumnya, proses konseling banyak memberikan perhatian terhadap aspek-aspek psikologis baik konselor maupun konseli. Sehingga melupakan terhadap latar belakang budaya konselor maupun konseli yang sebenarnya ikut andil dalam pembentukan perilaku serta menentukan efektifitas konseling. Misalnya penggunaan komunikasi non verbal, sentuhan untuk memotivasi, dan lain sebagainya, hal ini secara kental mengandung muatan budaya (Iswari, 2017). Seakan-akan intervensi atau perlakuan yang 
dilakukan dalam proses konseling hanya berfokus pada teori konseling saja, dan tidak menyentuh dinamika budaya konseli. Padahal budaya juga perlu dipertimbangkan dalam sebuah interaksi manusia.

Memasuki interaksi konseling dengan seseorang dari latar belakang budaya yang berbeda membawa tantangan yang unik serta peluang yang melekat (Lee, 2013b). Memahami peran budaya yang kompleks dalam proses konseling memang menjadi suatu tantangan tersendiri dalam praktik konseling. Budaya kadang berpotensi menjadi sumber konflik dan kesalahpahaman. Salah-salah budaya menjadi penghalang dan penghambat praktik konseling. Karena terlibat dalam hubungan ini (perbedaan budaya), artinya seseorang berada dalam potensi bermasalah.Oleh sebab itu, pengetahuan tentang realitas budaya menjadi suatu keharusan profesional ketika konselor menghadapi kelompok konseling yang beragam.

Budaya bisa menjadi dinding pemisah dan menjadikan interaksi konseling menjadi berjarak. Terciptanya dinding pemisah ini bisa disebabkan karena perbedaan budaya antara konselor dan konseli tidak dihargai dan dipahami. Sehingga dapat menjadi hambatan serius dalam praktik konseling. Perbedaan budaya yang diabaikan dan disalahpahami akan memperlebar jarak antara penolong dan orang yang ditolong. Tentunya ini bukanlah hubungan terapeutik yang dikehendaki dalam praktik konseling.

Namun sebenarnya, menurut Pedersen bahwa keragaman adalah aspek dasar dari semua konseling dan hubungan antara konselor dan konseli adalah pertemuan lintas budaya (Pedersen, 1991). Erford dalam Wibowo juga menyebut bahwa semua koneling adalah multikultural, karena setiap konseli yang datang dalam proses konseling dibentuk oleh beragam pengalaman budaya (Wibowo, 2018). Maka konseling berwawasan multi budaya merupakan praktik konseling yang memiliki kepekaan budaya dan mampu melepaskan bias-bias budaya (konselor dan konseli), mengerti, memahami dan mengapresiasi keragaman budaya, serta memiliki keterampilan yang responsif budaya. Karena sejatinya praktik konseling merupakan perjumpaan budaya (cultural encounter) antara konselor dan konseli dengan latar belakang budaya yang berbeda-beda satu sama lain. 


\section{Kontruksi Konsep Literasi Global}

Literasi budaya merupakan kemampuan dalam memahami dan bersikap terhadap kebudayaan sebagai identitas suatu bangsa (kemendikbud: 2017). Literasi global dibangun atas dasar pemahaman-pemahaman terhadap keberagaman budaya. Penerimaan seseorang terhadap budaya, mengakui dan keterlibatan terhadap keragaman menjadi menjadi pijakan konseling responsif literasi global. Ia akan berdiri tegak di atas penerimaan keragaman budaya. Tanpa hal itu, pemahaman terhadap dunia global tidak mungkin di dapatkan. Maka hal yang dibutuhkan adalah sikap sadar akan budaya.

Konseling yang kompeten secara budaya tidak akan terwujud jika konselor tidak memiliki kesadaran budaya. Bahwa kesadaran budaya perlu dipelajari oleh konselor selain aspek-aspek teori konseling. Konselor memerlukan pengetahuan lain untuk mendukung kemampuannya dalam profesi menolong. Kesadaran budaya ini tidak hanya berlaku pada pribadi konselor melainkan juga terhadap konseli. Pihak-pihak yang terlibat dalam praktik konseling dipahami memiliki kesadaran akan keragaman masingmasing individu. Kesadaran budaya ini dipelajari oleh konselor melalui pembacaanya tentang keragaman. Artinya kemampuan literasi budaya diperlukan diawali melalui proses peka dan menghargai terhadap budaya, dan meyakini budaya sebagai akar pembentuk sikap.

Konsep literasi global dalam konteks konseling multibudaya diperkenalkan oleh Courtland C. Lee. Lee menyebut ada empat pondasi dasar bagi konseling yang responsif budaya satu diantaranya adalah global literacy, tiga yang lainnya adalah self awareness, foundational knowledge of traditional counseling theory, dan ethical knowledge and aspiration. Ia lebih menyoroti pada diskusi tentang literasi global karena menurutnya dunia hari ini mengharuskan individu untuk selalu terhubung. Literasi global dipahaminya sebagai meluasnya informasi yang memasuki domain utama keragaman manusia (Lee \& Park, 2013). Kita tahu bahwa era ini mengharuskan seseorang untuk selalu terhubung dengan orang lain atau dunia di luar dirinya agar mampu mengarahkan kehidupannya.

Dunia baru yang diciptakan oleh teknologi informasi disebut dunia maya, cyber social, memungkinkan orang terhubung dengan latar belakang budaya yang beragam 
dan saling terkait satu sama lain. Kehadiran teknologi ini bahkan tidak pernah dibayangkan oleh manusia sebelumnya. Manusia tidak mungkin bisa menghindar, hidup secara ekslusif memisahkan dirinya dengan interaksi keragaman budaya. Dunia baru cyber social telah mendorong manusia untuk menjadi inklusif bahkan pluralis terhadap keragaman budaya. Secara perlahan, ekslusifitas akan terkikis oleh kehadiran dunia baru ini. Oleh sebab ini, literasi budaya dalam konteks lokal, perlu diperluas sejalan dengan keluasan akibat dampak kehadiran teknologi informasi.

Lee menyebut perlunya membingkai ulang konsep literasi budaya sebagai literasi global (Lee, 2013a). Literasi global menyiratkan pemahaman tentang dunia kontemporer dan bagaimana ia berkembang dari waktu ke waktu. Maka pemahaman budaya perlu didukung dengan pengetahuan dalam bidang sejarah, geografi, antoropologi, sosiologi, politik, agama dan lain sebagainya. Rasionalisasinya adalah, konseling multikultural tidak mampu berdiri sendiri dengan hanya mengandalkan teori konselingnya, melainkan juga perlu mempelajari budaya serta melengkapi dengan pengetahuan pada bidang-bidang yang telah disebutkan di atas.

Lee menambahkan, inti dari pengetahuan yang diperoleh seseorang selama hidupnya tentang dunia tempat dimana ia tinggal itulah yang disebut sebagai literasi global. Kekuatan pendorong dibalik kekuatan literasi global itu adalah komitmen yang dibuat seseorang untuk memastikan bahwa ia terbuka terhadap keragaman budaya, dan itu dijadikan sebagai landasan hidupnya. Literasi global tidak hanya mengakui keberadaan keragaman budaya, namun ia menerima keragaman tersebut dan mau berkomitmen untuk membiarkan keragaman sebagai kenyataan yang harus dipertahankan.

Seseorang yang hanya mengakui adanya keragaman budaya, bisa jadi seseorang tersebut tidak menerima keragaman itu dengan klaim latar belakang budayanya yang benar. Dan mengintervensi latar belakang budayanya ke dalam praktik konseling dan meyakini apa yang ia yakini adalah benar. Kemudian, seseorang yang menerima keragaman ia akan menghargai perbedaan dan kebenaran budaya masing-masing dan masih dipertanyakan komitmennya untuk merawat keragaman. Sementara itu, literasi global membutuhkan pandangan seseorang untuk mengakui keragaman, menerima 
keragaman dan berkomitmen terlibat aktif membiarkan keragaman itu sebagai sesuatu yang alamiah. Karena keyakinan bahwa semua itu memiliki kebenaran masing-masing yang tidak bisa disalahkan dengan dasar budaya pribadi.

Maka, kompetensi multikultural adalah tujuan dari praktik konseling profesional, sementara literasi global adalah tujuan yang dijalani dengan cara yang kompeten secara budaya. Oleh karena itu, seseorang tidak mungkin menjadi konselor yang kompeten secara budaya jika ia bukan orang yang melek secara global. Bahwa pengembangan literasi global adalah sebuah proses seumur hidup yang berakar pada komitmen untuk menjalani kehidupan dengan cara menjadikan keanekaragaman budaya sebagai prinsip inti. Ia mengakui, menerima dan berkomitmen terlibat aktif dalam upaya merawat keragaman sebagai sesuatu yang alamiah.

\section{Menjadi Pribadi Melek Literasi Global}

Untuk mencapai kesadaran literasi global, seseorang terlebih dahulu harus mengenali budayanya sendiri, artinya menguasai kompetensi literasi budaya. Lee menawarkan beberapa hal untuk mengembangkan kemampuan seseorang dalam literasi global (Lee, 2013a).

Pertama, seseorang perlu mengalami keanekaragaman secara langsung. Cara terbaik untuk belajar tentang keragaman adalah mengalami hal itu secara langsung, terlibat aktif dalam masyarakat majemuk. Hidup dalam masyarakat heterogen akan melatih kepekaan seseorang terhadap kemajemukan. Berdampingan dengan orang-orang dari latar belakang budaya akan memiliki kesan tersendiri. Seseorang akan saling bertukar informasi mengenai budayanya satu sama lain. Tanpa disadari tindakan ini akan memupus sekat perbedaan, meruntuhkan dinding pemisah. Pandangan-pandangan seseorang yang hidup dalam keragaman akan lebih luas, ia memiliki pengalaman dalam menghadapi situasi-situasi yang berbeda-beda.

Kedua, seseorang harus menikmati beragam keindahan budaya. Menikmati keindahan keragaman budaya akan sulit diterima jika seseorang pertama kali tidak mengakui adanya keragaman. Maka pengakuan akan realitas budaya yang beragam 
menjadi key point untuk menuju pada kemampuan menikmati keragaman. Bisa jadi, melihat pertunjukan kesenian dari luar daerahnya sendiri akan melatih kemampuan menikmati keindahan budaya. Namun yang terpenting adalah menghindari klaim budaya sendiri lebih baik dari pada budaya yang lain. Karena sikap ini akan mendorong seseorang pada fanatisme buta.

Ketiga, mengikuti perkembangan acara terkini, atau bahasanya adalah update. Era kemajuan teknologi informasi mendorong seseorang untuk mengatahui informasi yang datang dari belahan dunia lain secara cepat. Teknologi informasi menjadikan manusia dapat mengakses kebutuhan dirinya secara cepat dan efisien. Dua dekade yang lalu, televisi, koran, radio menjadi media untuk mendapatkan perkembangan informasi terkini. Namun kehadiran internet mengungguli ketiga media tersebut. Internet bisa menjadi solusi kecepatan penyebaran arus informasi dan penerimaan perkembangan informasi secara cepat. Maka, jika seorang konselor tidak menguasai dalam bidang ini, bisa jadi ia tidak mampu maksimal dalam praktik konseling yang kompeten secara budaya.

Sebagai tambahan, seseorang yang hendak menguasai kompetensi konseling secara budaya - budaya global, ia tidak hanya cukup belajar melalui buku-buku konseling, mengikuti kelas-kelas seminar dan menjadi pembicara disana-sini. Ia harus mampu membaca budaya, mengembangkan sensitifitas budayanya, melatih kepekaan terhadap keragaman, membaca situasi sosial yang berkembang di masyarakat. Pengetahuannya harus melampaui budaya lokal, bergerak menuju dunia global, dan memahami problem-problem sosial secara holistik. Kemampuan itu akan ditunjang dengan banyak membaca buku-buku bidang sejarah, sosial, geografi, ekonomi, antorpologi, agama, politik-geo politik, sistem pemerintahan dan lain sebagainya. Sebagai kalimat akhir, konseling yang kompeten secara budaya tidak bisa hanya dipelajari di kelas, melainkan seseorang harus mengalami langsung dimensi-dimensi keragaman budaya itu sendiri. 


\section{KESIMPULAN}

Sejatinya konseling adalah suatu perjumpaan budaya yang berbeda antara konselor dan konseli. Oleh sebab itu praktik konseling seharusnya bukan sebagai aktifitas memaksakan budaya satu pihak. Konselor perlu memahami kembali, kaitannya dengan konseling yang kompeten secara budaya, bahwa profesi konselor adalah suatu cara hidup. Kehidupan seseorang harus dijalani dengan cara yang mencerminkan komitmen untuk terus memperluas zona kenyamanan budaya seseorang untuk memasukkan pengetahuan dan interaksi aktif dengan orang-orang dari berbagai latar belakang budaya. Ini berarti seseorang secara konstan menyadari bagaimana peristiwa, baik di masa lalu maupun saat ini berdampak pada kesejahteraan seseorang. Oleh sebab itu, literasi global tidak dapat dipelajari di ruang kelas, melainkan hal itu adalah upaya seseorang untuk menjadi pembelajar seumur hidup dari keragaman budaya dan warga dunia.

\section{DAFTAR RUJUKAN}

Ghafur, W. A. (2014). Dakwah Bil Hikmah di Era Informasi dan Globalisasi: Berdakwah di Masyarakat Baru. Jurnal Ilmu Dakwah, 34(2), 236-258.

Iswari, M. (2017). Efektivitas Penyelenggaraan Konseling dengan Memahami Komunikasi antar Budaya. Konselor, 6(1), 13-17.

Kemendikbud. Bimbingan dan Konseling Pada Pendidikan Dasar dan Pendidikan Menengah. , Pub. L. No. 111 (2014).

Kementerian Pendidikan dan Kebudayaan. (2017). Panduan Gerakan Literasi Nasional. Jakarta: Kementerian Pendidikan dan Kebudayaan.

Lee, C. C. (2013a). Global Literacy: The Foundation of Culturally Competent Counseling. Dalam Multicultural Issues in Counseling: New Approaches in DIversity (4 ed.). Alexandria: American Counseling Association.

Lee, C. C. (2013b). The Cross-Cultural Encounter: Meeting the Challenge of Culturally Competent Counseling. Dalam Multicultural Issues in Counseling: New Approach to Diversity (4 ed.). Alexandria: American Counseling Association.

Lee, C. C., \& Park, D. (2013). A Conceptual Framework for Counseling Across Cultures. Dalam Multicultural Issues in Counseling: New Approaches in DIversity (4 ed.). Alexandria: American Counseling Association. 
Rosyada: Islamic Guidance and Counseling

Vol 1. No. 12020

Pedersen, P. B. (1991). Multiculturalism as a generic approach to counseling. Journal of Counseling \& Development, 70, 6-12.

Sue, D. W., \& Sue, D. (2012). Counseling the Culturally Diverse: Theori and Practice (6 ed.). New York: Wiley.

Wibowo, M. E. (2018, April 27). Konseling Multikultural di Abad-21. 1-18. Pekanbaru.

Wijaya, A. (2019). Kontestasi Merebut Kebenaran Islam di Indonesia: Dari Berislam secara Teologis ke Berislam secara Humanis. Yogyakarta: IRCISOD. 